\title{
Power relations in the family health team: focus on nursing
}

\author{
Relações de poder na equipe de saúde da família: foco na enfermagem \\ Relaciones de poder en el equipo de salud familiar: foco en la enfermería
}

\section{Iramildes Souza Silva', Cássia Irene Spinelli Arantes'}

'Universidade Federal de São Carlos, Postgraduate Program in Nursing. São Carlos, São Paulo, Brazil.

How to cite this article:

Silva IS, Arantes CIS. Power relations in the family health team: focus on nursing.

Rev Bras Enferm [Internet]. 2017;70(3):580-7. DOI: http://dx.doi.org/10.1590/0034-7167-2015-0171

Submission: 03-02-2016 Approval: 11-26-2016

\section{ABSTRACT}

Objective: to analyze the power relations that permeate the work of the family health team, and to discuss perspectives of emancipation of these subjects, focusing on nursing and community health agents. Method: a qualitative study with a family health team from a municipality in the countryside of the state of São Paulo. Data were collected through systematic observation and interview with workers. A thematic content analysis was performed. Results: three categories were identified: the work of the family health team and power relations; power relations between the nurse and the healthcare team; and the relations among the nursing team and between community agents and the nurse. The team produces relations of power moved by hierarchical knowledge that move in the search for the reordering of powers. Final considerations: it is necessary to review the contradictions present in the performance scenario of the family health teams, with a view toward making power relations more flexible.

Descriptors: Family Health; Health Team; Power (Psychology); Nursing; Interpersonal Relationships.

\section{RESUMO}

Objetivo: analisar as relações de poder que permeiam o trabalho da equipe de saúde da família e discutir perspectivas de emancipação desses sujeitos, com enfoque na enfermagem e agentes comunitários de saúde. Método: estudo qualitativo com equipe de saúde da família de município do interior paulista. Os dados foram coletados por meio de observação sistemática e entrevista com os trabalhadores. Foi realizada análise de conteúdo temática. Resultados: foram identificadas três categorias: o trabalho da equipe de saúde da família e as relações de poder; a relação de poder entre enfermeira e equipe de saúde; as relações da enfermagem e agentes comunitários com a enfermeira. A equipe produz relações de poder movidas por saberes hierarquizados que se movimentam na busca pelo reordenamento dos poderes. Considerações finais: é necessário rever as contradições presentes no cenário de atuação das equipes de saúde da família, com vistas à flexibilidade nas relações de poder. Descritores: Saúde da Família; Equipe de Saúde; Poder (Psicologia); Enfermagem; Relações Interpessoais.

\section{RESUMEN}

Objetivo: analizar las relaciones de poder que permean el trabajo del equipo de salud familiar y discutir perspectivas de emancipación de tales sujetos, con enfoque en la enfermería y agentes comunitarios de salud. Método: estudio cualitativo con equipo de salud familiar de municipio del interior paulista. Datos recolectados mediante observación sistemática y entrevista con los trabajadores. Se realizó análisis de contenido temático. Resultados: fueron identificadas tres categorías: el trabajo del equipo de salud familiar y las relaciones de poder; la relación de poder entre la enfermera y el equipo de salud; las relaciones de la enfermería y los agentes comunitarios con la enfermera. El equipo determina relaciones de poder movilizadas por conocimientos jerarquizados, en constante movimiento en búsqueda del reordenamiento de los poderes. Consideraciones finales: es necesario revisar las contradicciones presentes en el escenario de actuación de los equipos de salud familiar, apuntando a flexibilizar las relaciones de poder.

Descriptores: Salud de la Familia; Grupo de Salud; Poder (Psicología); Enfermería; Relaciones Interpersonales. 


\section{INTRODUCTON}

The Family Health Strategy (FHS) emerges in Brazil as a way to reorient the care model in basic care, in accordance with the principles of the Brazilian Unified Health System (SUS), proposing a way of doing health work under a new understanding that focuses on the family and the team ${ }^{(1)}$. It is thought that this model has the potential to achieve greater effectiveness in the health system, mainly due to the new way of health care centered in teamwork ${ }^{(2)}$.

However, it is necessary to emphasize that teamwork is built on a daily basis and represents a process of relations to be thought of by the workers themselves from the perspective of numerous possibilities and developments when articulating different types of knowledge ${ }^{(3)}$.

Historically, these types of knowledge were born at different times, were autonomized according to specific and particular scientific rationalities, and were institutionalized according to the construction of hierarchies of recognition and legitimation of the stratification of social prestige that has produced positions of unequal value among health sciences ${ }^{(4)}$. Through knowledge, different subjects or specializations are proper territories where certain orders linked to strategies and power-plays circulate ${ }^{(5)}$. Therefore, it is possible to see the complexity around teamwork that has a close relation with naturalized knowledge, present in the praxis of each profession, and with power relations.

In this context, nursing, as a social practice, brings several questions to the discussion, about nurses' knowledge, work, boundaries, possibilities, roles, and relationships with other professions in the health field. This is inserted into the field of professional identities, a field of institutionalized segmentations. Its limits are weighed that is, what is and what is not the attribution and responsibility of this professional group and of each category that composes the nursing team, demarcating the field of conflicts and disputes in the field of political, legal, juridical, educational, and social-class practices ${ }^{(6)}$. In this arena of tension, the insertion of community health workers ( $\mathrm{CHWs}$ ) into the family health $(\mathrm{FH})$ team is included. Despite being part of the nursing team, they are coordinated by nurses, although the law in force does not clearly give this responsibility to the nurse $\mathrm{e}^{(7)}$. These workers, in many situations, do not feel that they belong to the team, and are referred to by professionals as "another team" that articulates with that of FHS professionals, which gives rise to conflicts between workers ${ }^{(8)}$.

Teamwork in health care is seen as a network of relationships among people, a network of relations of powers, knowledge, affections, interests, and desires, in which it is possible to identify group processes. Working within a team is equivalent to relating to others ${ }^{(2)}$.

Therefore, the work process of the health team is crossed by several noises, among which are the tensions generated by the hierarchy among the various categories ${ }^{(2)}$, tensions that can unfold in power relations. These relations are expressed in practices among workers under different aspects, and permeate the work process, either in communication that, in the FHS despite the discourse committed to participation, persist in traditional forms: dominant; vertical; and authoritarian speeches $^{(9)}$ or in the still dominant medical centralization ${ }^{(2)}$.
In this sense, acting in an integrated manner, beyond the hierarchical technical work, is a challenge for the $\mathrm{FH}$ team, and there is a need to review the process of subjection, and the knowledge/power relationships that are established in the daily work, with a tendency to become naturalized ${ }^{(7)}$.

Teamwork involves a struggle between instituted and instituting forces, and from these movements the challenge of making other bets and investing in other types of logic emerg$\mathrm{es}^{(10)}$. This includes reviewing the relations of micropowers that are established in the act of caring.

The focus of interest of this investigation is located in this scenario, and we question: How are the relations of power produced in the work of the FH team? What possibilities could be evidenced in the deconstruction of the asymmetries of power among FHS workers? It is assumed that, to move towards making relations among $\mathrm{FH}$ workers more horizontal, with a focus on the production of integral healthcare, it is necessary to dissect the web of power present in the work of the FHS team.

This study aimed to analyze the power relations that permeate the work of the family health team, focusing on the nursing team and CHWs, and discussing the perspectives of emancipation of these subjects in their field of action.

\section{METHOD}

\section{Ethical Aspects}

The research project was approved by the Human Research Ethics Committee of the Federal University of São Carlos. The Free and Informed Consent form was explained to the subjects, who accepted and signed it, agreeing to participate in the research, in compliance with the resolution of CNS 196/96 (Brazilian Health Council, 1996). The subjects of the study were identified by the initial letter of the professional category to which the interviewee belonged, or by their role, through the following acronyms: Nurse $(\mathrm{N})$; Nursing Technician (NT); Physician (P); Dentist (D) and Community Health Worker $(\mathrm{CHW})$. In the professional categories in which there was more than one worker, an ordinal numeral was added, following the sequence of interviews.

\section{Theoretical-methodological reference}

The theoretical anchorage was based on references in the health work process, already cited in the introduction, and on power, especially as described in Foucault's studies The Microphysics of Power ${ }^{(11)}$ and Discipline and Punish ${ }^{(12)}$. Within this theoretical framework, the following categories of analysis were established: work process and health care; teamwork in $\mathrm{FH}$; power relations in the health team; and conflict in the health field. The present study is descriptive and exploratory, with a qualitative approach.

\section{Methodological procedures}

Systematic observation was conducted, guided by a basic script, focusing on team interactions totaling approximately 40 hours. The information was recorded in a field logbook (FL). Semi-structured interviews were carried out with $16 \mathrm{FH}$ professionals: one nurse; one physician; five community health agents; 
three nursing technicians; one administrative agent; two dentists; two oral health assistants $(\mathrm{OHA})$; and one health manager $(\mathrm{HM})$.

\section{Study setting}

The setting was a family health unit of a municipality in the countryside of the state of São Paulo that has, in its basic care network, $24 \mathrm{FH}$ teams, 10 teams working in conventional basic units, and one NASF-SF support center ${ }^{(13)}$. The criterion for choosing the team considered the time the workers spent in joint action in the same space for more than one year.

\section{Data collection and organization}

Data collection took place in the last week of September and the first week of October, 2012. The interview script was guided by questions that dealt with the relationships among workers. The interviews lasted an average of 50 minutes each. They were audio-recorded and fully transcribed, preserving the anonymity of the participants.

\section{Data analysis}

Data were analyzed with the content analysis method, using the thematic categorical analysis technique ${ }^{(14)}$. The analysis process was based on the theoretical framework and gave rise to three categories: the work of the $\mathrm{FH}$ team and the relations of power; the power relation between the nurse and the $\mathrm{FH}$ team; and the relations between the nursing team and $\mathrm{CHWs}$ with the nurse.

\section{RESULTS}

\section{Family health teamwork and power relations}

There was evidence that the microspace in which the $\mathrm{FH}$ team works is permeated by modes of subjectivity inherent to human relations and established in everyday life, expressed in power relations. These emerge from disputes involving different mechanisms of action between the different professional categories:

The case of a hypertensive client who came to the clinic every day, did not take the medication, the pressure was thirteen/ten, [...] those complaining patients, I dismissed after guiding her. She "passed by" an CHWs on the street and commented that I had dismissed her. The CHWs came to me angrily, saying that the client was hers, whoever heard of dismissing a patient [...]! I said: She came to seek nursing reception, when looking for you as a community agent is something else [...]. I think she (CHW) cannot interfere with my service, the same way I have to respect hers. (NT 1)

\section{[...] I come, I really fight [...] We "lash out." (CHW)}

Power [...] I think everyone has it, but the ones to have the highest power are the nurse and the doctor. They have a more leadership, boss position, the nurse in a more "roughneck" way, and the doctor is kinder in the way he talks. (D2)

Power relations can be expressed in the imposition of the opinions of certain components of the team, from relationships that seem to follow a vertical hierarchical line, possibly influenced by the position that the worker occupies:
I say that we have to work beyond the unity, as the walking group [...] the technicians have to alternate and follow up. The nurse said it's impossible, and nobody contradicts it; the program says we have to work out there as well. This imposition is power. If everyone gave their opinion and she argued [...] but one person decides for the team, this for me is to use power! (NT 3)

There is the power of hierarchy [...] some things are imposed on us [...] the manager comes here and says we have to do things yesterday; we do not have lunch and he does. CHWs have to do everything. In this situation there isn't a team in this case; we have to run after things. (CHW 3)

If I did not respect hierarchy, certainly I wouldn't be here anymore [...]. (CHW 4)

In family health, power would be the leadership capacity, regardless of hierarchy. It could be me, the nursing technician, or the doctor, the one who has a vision and facility to solve some things. But today for me the power is related to the hierarchy of the position. (CHW 5)

Here we have leadership imposed by the position. (OHA 1)

Although the position of nurse as supervisor offers attributes of power, it is noticeable that, even in a relationship that seems to be hierarchical, there are expressions of power rearrangement, either through the democratization of relations, or through conflict, opening gaps for a certain degree of autonomy:

We "fight" with the coordination. (CHW 1)

[...] But we organize ourselves. We do and it gets right; we impose ourselves and do it. (CHW 2)

There may be an expropriation of power relations as something inert or based on someone. Workers reported that everyone, in some way, can exert power:

Power is to be able to influence people [...] I do not have full power; I am not the one who pushes around. Power, everybody has, some more, others less. Like me and the dentist; she's graduated, but I also say no to some things, and she depends on my service to make hers. (OHA 1)

Also in the relations of those involved in the study, power can function on a provisional basis, changing among team members:

They brought a difficult problem of a client; I gave an opinion and the team agreed. For a long time it worked to soften; then it had to change, at the suggestion of someone else. (NT 3)

The power relation between nurse and family health team The nurse's exercise of power in relation to the team appeared more expressively in the speeches. The results showed that even the physician, culturally considered as a professional who brings hegemony to the work relations, recognizes in the figure of the nurse someone who exercises power in and on the team: 
Historically, the nurse has always been the most influential person, who makes the most vehement decisions [...] has the vocation to lead, bring problems, and try to find solutions in the clinic operation, in the activities of each one, even my activity [...]. The flow diagrams of care [...] the secretary usually sends to the team by e-mail, but initially these guidelines come to the nurse's hand, then she passes to me [...] who will do what and how. I think she has a great power in this kind of determination. $(\mathrm{P})$

The doctor's speech also shows that the health secretary herself, as a power structure from the perspective of a central management body, provides the convergence of power for certain professionals in this area, particularly for the nurse.

According to some reports, the nurse is the one who most influences the work process and, therefore, plays a more central role in the team's decisions, acting as regulator of the work process experienced:

The nurse has a quick action, which impacts the team. Most ideas come from her. If you have to talk about any problem, it is with her. If the doctor has any urgent problems, talk to her. The agents too [...] as if she were a reference. I, first I go to her [...] the way I'm going to act depends on her opinion. (NT 3)

People highly respect the opinion of the doctor here on the team, but the nurse is the person to be consulted regarding a new demand. (D2)

The head nurse, who runs the team, with her way of working. (CHW 4)

The condition of the nurse as protagonist in certain moments experienced by the group of workers, such as that of the team meeting, gives her a differentiated position on the relationship established with the team. She seems to be the one who most exposes her point of view and who problematizes, including what is placed by the team, such as cases involving families and clients, internal administrative events and new proposed actions:

Team meetings without her do not flow very well, because she has a more determined posture to solve some situations that others postpone. $(\mathrm{P})$

As observed in team meetings, the nurse is the person who speaks most of the time. It is she who directs the meeting, including mobilizing the others, in the decision-making of the cases that arise, using expressions such as: "Do you agree?", "Who is going to do?" (FL)

On the other hand, the nurse herself reports that with the team there is not a relation of power, but of affinity, at different levels. She also proposes the expression "initiative" instead of "power" to talk about her interaction with the team:

Power is a very strong thing. I can particularly be part of the team, suggest things [...] but not have power over the team. Here we have no power; we have initiative, sharing, commitment, respect, and have affinities, more with some, less with others. But power in the direction of a command, here we do not have it; we always ask for it. (N)
Other testimonials from the nurse provide support to consider their relationship with the team from the perspective of power relations, from their professional trajectory in basic care:

The nurse in general [...] I will talk about this city hall [...] When I came in, I was raised [...] as a boss, who even give commands to the doctors. I had to check and "close" the doctor's attendance, and that for many years. When I came to USF, after a while that was gradually demystified. I do not have the power to tell anyone here. I work with them, I look very horizontally. The same right and power they have I also have. But some things still focus on the nurse. They come to ask for me. $(\mathrm{N})$

In the traditional UBS here, all nurses have power! They push around. This is what the city hall requires. Now in the PSF, as they [managers] are looking more at the team, then that power does not exist, at least here. Sometimes I talk and I have an idea; I ask if the staff has availability, but I do not give orders. (N)

It seems that the nurse has, historically, an aptitude or disposition to be involved with problems that arise in the daily work, with the intention to solve them, mainly to facilitate the work of the other professionals. It is possible that there is a passivity of the other elements of the team when facing difficulties to be solved. This could favor a position of dominance and power of the nurse over the team.

\section{The relations of the nursing team and community health agents with the nurse}

Some testimonies point out that the nurse has the role of organizing the work for the nursing team and $\mathrm{CHWs}$, with a coexisting relationship that promotes learning in terms of technical and administrative knowledge:

Much of what I know today I learned from the nurse who helped me a lot in the beginning, who gave me a lot of good things here, a lot of experience of her own, because we came from SAMU, which is emergency. And here you see a lot of health promotion. (NT 3)

I learned a lot with her in terms of technical organization. (CHW 1)

She is highly capable, knows how to work, is very organized. (NT 1)

The nurse seems to support them and maintain certain conditions of internal organization in the unit, to help the population with proposals for receiving them:

She worries about the programs, the health promotion, the families, the people she sees. To be welcomed, this is not easy. (NT 3)

Considering that teamwork requires a continuous exercise of self-analysis, the nurse is seen as someone who mobilizes this process through something that the worker refers to as "charge":

It charges us a lot, but the charge, in this case, is a means of even seeing how our service is. Sometimes I question the 
reason for the charge, and the interesting thing is that I can correct lots of things. (NT 2)

The study also presented a perspective of a hierarchical relationship of knowledge/power that places the nurse as having greater knowledge in the graduation scale that seems to evidence a verticalization of knowledge:

Sometimes it was possible to observe that the nurse was only consulted by the technicians in some situations that demanded an opinion of greater complexity, such as puncturing a more difficult venous access, evaluating a suspected case, a doubt in a child's vaccination schedule, breast evaluation of a nursing woman, among others, and the $\mathrm{CHWs}$ looked for her when they needed more administrative information that could direct them in decision-making. The latter had less time on the nurse's agenda, who had many bureaucratic activities in the unit. (FL)

This hierarchization of knowledge seems to produce a certain domain condition, especially in relation to $\mathrm{CHWs}$ :

Sometimes there are some conflicts because of the nurse's different view of our work. She is one of those older one; they have an old vision of what the PSF is. [...] we "fight" with some ideas [...] I learned in the introductory period that the team is linear, it has to have someone to coordinate, but not to rule. The one who coordinates cannot prevent me from doing my job well and feeling that what I know and do is less important. (CHW 1)

I feel a barrier between nurse and CHWs [...] I feel inferiority [...] The way she talks about some issues bothers me; sometimes it seems that she depreciates my work a little, what I know. And I get blocked. (CHW 5)

In contrast, the $\mathrm{CHW}$ reports that the fact of being able to conflict with the nurse gives her the possibility of getting along with her; otherwise she would be annulled in her right of expression:

My relationship, in general, with the nurse is good, although several times I had to "fight" with her; otherwise I would be a very depressed person. (CHW 5)

\section{DISCUSSION}

The results presented make it possible to think that power relations in the $\mathrm{FH}$ team also require a look at the subjectivity present in the act of caring, imbricated in the way the worker means the work, which is not only a characteristic of the objectivity of the various types of structured knowledge, but it runs through the individual repertoire of the subjects, which dialogues with the ways of feeling, seeing, making life run, as well as with their expectations, wishes and interests.

The discussions about the relations among these workers are very complex and go through the professional practices and the production of subjectivities of these subjects that relate to the world by shaping their behaviors, making them unique ${ }^{(15)}$.

It is a question of the micro-politics of the organization of work processes that establishes a place of permanent tension because the interests can be diverse, with the coexistence of a field of strong dispute for the senses and meanings of the encounters between the subjects ${ }^{(16)}$.

In these meetings, power relations are present both explicitly and implicitly, as shown in the reports of $\mathrm{FH}$ team professionals involving the different categories in action. It has been shown that these relations of power are not unilateral nor fixed, but they circulate in micro-relations, in different directions, do not lack varied and subtle modes of operation, and may even become stronger through this mechanism. They do not have a single flow or apparent symmetry, because they manifest themselves in the different team arrangements involving workers who are not passive subjects, but rather actors involved in the processes in which they participate.

In this environment, one looks at the proposition that involves the interdisciplinary team in $\mathrm{FH}$, inserted in a field of continuous struggles that require overcoming "giants" in real time. After all, the general training of each health professional is still strongly guided by the individualism that gives the professionals in each area the tendency to work in isolation and independently from others; teamwork, the division of power, and joint decision-making are very difficult in daily work ${ }^{(17)}$.

Especially in the field of collective health, there are tensions of a disciplinary and epistemological nature ${ }^{(18)}$ and, in the organizational dimension of health services, the technical and social division of labor, which highlights new elements such as teamwork, which depends on the cooperative action of various actors to be achieved in spaces often interspersed by divergence, difference, disputes, and asymmetries of power ${ }^{(19)}$.

However, this scenario is considered as fertile to promote a displacement of power, capable of negotiating, within the health teams, autonomizing movements, through the distribution, dilution, and capillarization of power. In it, workers interact in the search for recognition of professional capacity, class valuation, personal ability, style of relating or positioning in the face of problems, a value, and a social place ${ }^{(20)}$. This is not to imagine completely autonomous workers, exempt from any external form of traditional control, independent and uncommitted. Paradoxically, the extension of autonomy depends on the ability of the subject to recognize and deal with the network of dependence in which all are inevitably immersed ${ }^{(21)}$. It requires a dynamic process that involves progressive losses or gains.

In the work process of the studied team, the discourses produced, the confrontations, the conflicting relations, and the contradictions mark the universe of action of the subjects when articulating to produce care, evidencing a contraposition to the power instituted through the position or independent from it, evidencing the productive face of power, because its capillarity creates movements from top to bottom and from bottom to top, reaching all the places in the network ${ }^{(11)}$.

From this direction, it is possible to review the power relations existing in the $\mathrm{FH}$ team, from the perspective of seeking to understand this mobility of forces that alternate in their inner side, crossing the whole body, either present in the nursing practice or exercised by other members of the team, as verified in the reports, exposing the temporary nature of power.

The findings of this study, unlike others that situate the figure of the physician as central in the team ${ }^{(22)}$, present the 
nurse as the member of the team who most seems to exert power over the others. However, more closely considering the situation of nursing as a profession, we are authorized to suggest that the evidence of power exercised by the nurse exposes an ambiguity, because this can work in the practice of actions in $\mathrm{FH}$, as demonstrated in the statements, but does not materialize in the established social, economic, political, and legal relationships, and is not a fully recognized power in these instances. The expression of this is given, for example, in population care, where decisions are taken by physicians and managers, who may be doctors, or even in situations that require official opinions involving health issues, when it is common for medical professionals to be consulted.

The historical construction of the nurse's profession seems to grant the nurse attributions that are not so much related to the political aspects, but condition the nurse to technical exercise, increasing the supporting role that the nurse has been assuming. Even when the nurse has decision-making spaces, his/her identity is usually not evidenced, to the detriment of the position that gives him/her power ${ }^{(23)}$.

Nurses' visibility and inclusion in the sociopolitical sphere remain a challenge, although there seems to be an effort made by the category, even if incipient, to overcome the reductionist approach, as well as to assume exponential decisive spaces to lead and consolidate health policies.

From this perspective, it is the discussion on biopower-power over life ${ }^{(12)}$-that allows us to see the structure of medicine become, throughout history, the only practice capable of defining, through its scientific knowledge, what is normal and what is pathological, thus making the biological body an object of work, apprehended in medical practice, delegitimizing all other knowledge and practices in health, by dealing with non-real objects $^{(24)}$. This debate includes the knowledge of nursing as a profession, which has not yet been socially recognized ${ }^{(25)}$.

Thus, it is possible to think that this centrality that was pointed out, converged toward the nurse, has been validated by the team itself, and can be presumed as an apathy and circulating inertia in the group, which in turn remains in this "comfort zone" - that is, not desirous of being co-responsible for the problems that emerge, preferring silence to speech that questions and produces something different from quietnessin other words conflict, considering that power is also granted by the omission, accommodation, or submission of others ${ }^{(26)}$.

The results of this study also expose nurses' knowledge from the point of view of knowledge/power, when analyzing their relationship with $\mathrm{CHWs}$ and $\mathrm{TE}$, which seems to show the verticalization of knowledge.

Particularly in nursing, the vertical relation based on knowledge/power has, in a certain way, support in the legislation, built by the nurses themselves, that guides the category, because the nurse has the responsibility to supervise and coordinate others, coming from the nursing skill(27) and, more recently, from the $\mathrm{CHWs}$. This is a finding that power relations can pass through the scientificity of knowledge, which establishes the division and specialization of labor, determined by knowledge. These produce truths that, when regulated and institutionalized, establish relations of power. There is no relation of power without the constitution of a field of knowledge, nor is there knowledge that does not presuppose and does not constitute relations of power ${ }^{(11)}$.

Specifically in relation to the CHWs, a tension was identified involving the lack of valorization of their work. Nurses suggest that, by appropriating tools that they deem relevant to their work process, they do not find legitimacy on the part of those who supervise their actions, in this case, the nurse.

It seems that it is expected, on the part of this worker, that he or she receive parameters for the performance of the work; this presupposes more horizontal lines in the relations established in which technical knowledge prevails over the hierarchical one. Nurse coordination would thus have the task of strengthening, rather than limiting, the performance of $\mathrm{CHWs}$. One of the crucial functions of team coordination is precisely the construction of a positive interaction among professionals despite differences, not against differences ${ }^{(28)}$.

The expression "fight" posed by the CHWs refers to the idea of the exercise of power, showing that it is also present in the movements of resistance evidenced by the $\mathrm{CHWs}$, when they fight in the search for the visibility of the social value of their work, leading back to the understanding that the exercise of freedom is an exercise of power. That is, there is no exercise of power where there is no possibility of action and, also, there is no exercise of freedom where there is no exercise of power ${ }^{(29)}$.

A certain movement involving the $\mathrm{CHWs}$ was observed, in order to seek to disassociate the hierarchical line of knowledge/power. One of them reports that the fact of being able to conflict with the nurse gave him the possibility of getting along with the nurse, because otherwise he would be annulled in his right of expression. It could be said that the disagreements generated in the act of caring offer the potential for both the tutelage and the subjugation of subjects, as well as the possibility of forging emancipatory processes, in the sense of freedom for power/doing in health. This proposition echoes the assertion that interdisciplinary teams are favorable arrangements for the struggle for recognition and, consequently, for creative and cooperative work ${ }^{(20)}$.

The teams, when they do not repress the spaces of conflict, provide a constant subjective formation of the workers and an achievement of degrees of autonomy ${ }^{(20)}$.

Humans, in their daily lives, face each other, and confront each other in the smallest situations. They get involved, they manifest, they cross each other, they react, they obey, they comply with, they resist, they merge in the practice of power. But there is no relation of power among free subjects, there is the exercise of power in a constant movement of domination/resistance ${ }^{(30)}$. It is possible to say, from the reports, that the freedom of the subjects, in the resolution of the conflicts in the FH team, imply that they have a field of possibilities fertilized by the own interdisciplinarity that opens space for more symmetrical and less vertical relations.

\section{Study limitations}

We highlight as a limitation the impossibility of making generalizations, because this is a study that analyzed the power relations between workers of only one family health team. We recommend carrying out both studies that deepen the dynamics 
of the relations of other teams in different contexts, and research based on other theoretical and methodological references, in order to increase the number of teams and workers studied. Thus, it will be possible to reach a greater approximation of the complexity that configures the analyzed object.

\section{Contributions to the nursing area}

This study allowed, through Foucaultian theoretical assumptions, to evidence factors that interfere in the production of health care offered by nursing, and to invite the people involved to reexamine the power relations of the team, not as something to be denied or to imprison or that only subordinates, but as a libertarian possibility for nursing as knowledge, considering that it has, in its historical formation, a place of abnegation.

\section{FINAL CONSIDERATIONS}

This study made it possible to see that at the same time that the health team produces care, it also produces power relations. Tension poles were evidenced, materialized in the conflicting discourses of the workers, pointing to an exercise of accommodating and dismantling knowledge that sometimes verticalizes the relations and imprisons the subjects in the old practices, involving command and subservience to the detriment of the autonomy so desired in healthcare.

The conflict was presented as a sign of vitality in the team, with the fruitfulness of producing continuous disruptive movements capable of strengthening emancipatory processes and leading to a gradual deconstruction of inequalities among $\mathrm{FH}$ workers.

It has allowed the thought that one of the most permeable ways for FHS to bring about change is precisely in the openness that each worker can present, even as he or she possesses a body of knowledge of his or her own, seeing power as a circulating practice that alternates from place to place. It is concentrated in one or some and, as it is temporary, can constitute an instrumental manifestation in the $\mathrm{FH}$ to take care of people.

Community health workers have been engaged in transposing the hierarchical line of power/knowledge to power/doing. However, the way that health care is organized, historically based on the verticalization of knowledge, makes this shift much slower and more complicated for the team. One finding is the fact that nursing has legislation built by the nurses themselves and that, at the level of management, either in the municipality studied or in the staff itself, is reflected in the power relations that are established among the professionals that make up the nursing team and also among the CHWs.

The constructions of this study cannot be considered conclusions, but rather an indication of the paths to be followed in the search for gradual responses to the concerns raised here, which demand flexibility in power relations. The challenge is to review the contradictions present in the performance scenario of $\mathrm{FH}$ teams, and it is proposed that those involved reflect on their practices towards the emancipation process in the production of care in the FHS.

\section{REFERENCES}

1. Brasil. Ministério da Saúde. Política Nacional de Atenção Básica. Secretaria de Atenção Básica. Departamento de Atenção Básica [Internet]. Brasília: 2012 [cited 2016 Jan 16]. http://189.28.128.100/dab/docs/publicacoes/geral/pnab.pdf.

2. Oliveira HM, Moretti-Pires RO, Parente RCP. As relações de poder em equipe multiprofissional de Saúde da Família segundo um modelo teórico arendtiano. Interface [Internet]. 2011 [cited 2016 Jan 16]; 15(37):539-50. Available from: www.scielo.br/pdf/icse/ v15n37/a17v15n37

3. Viegas SMF, Penna, CMM. A construção da integralidade no trabalho cotidiano da equipe saúde da família. Esc Anna Nery Rev Enferm [Internet]. 2013 [cited 2016 Jan 16];17(1):133-41. http://www.revistaenfermagem.eean.edu.br/detalhe artigo.asp?id =825

4. Carapinheiro G. Os desafios dos saberes na investigação em saúde. Forum Sociológico [Internet]. 2014 [cited 2015 Oct 20 ]. Available from: http://sociologico.revues.org/985

5. Gregório VRP, Padilha MI. Strategies of power in the context of maternity Carmela Dutra: Florianópolis-SC (1956-1986). Texto Contexto Enferm [Internet]. 2012 [cited 2015 Oct 20];21(2):277-85. Available from: http://www.scielo.br/pdf/reeusp/v48n5/0080-6234-reeusp-48-05-899.pdf

6. Matumoto S, Fortuna CM, Kawata LS, Mishima SM, Pereira MJB. Nurses' clinical practice in primary care: a process under construction. Rev Latino-Am Enfermagem [Internet]. 2011 [cited 2015 Oct 04]; 19(1):123-30. Available from: http://www.scielo. br/pdf/rlae/v19n1/17.pdf

7. Silva JS, Fortuna CM, Pereira MJB, Matumoto S, Santana FR, Marciano FM et al. Supervision of Community Health Agents in the Family Health Strategy: the perspective of nurses. Rev Esc Enferm USP [Internet]. 2014 [cited 2016 Oct 02];48(5):899-906. Available from: http://www.scielo.br/pdf/reeusp/v48n5/0080-6234-reeusp-48-05-899.pdf

8. Carvalho BG, Peduzzi M, Ayres JRCM. Conceptions and typology of conflicts between workers and managers in the context of primary healthcare in the Brazilian Unified National Health System (SUS). Cad Saúde Pública [Internet]. 2014 [cited 2015 Oct 20];30(7):1453-62. Available from: http://www.scielo.br/pdf/csp/v30n7/0102-311X-csp-30-7-1453.pdf

9. Cardoso AS, Nascimento MC. Comunicação no Programa Saúde da Família: o agente de saúde como elo integrador entre a equipe e a comunidade. Ciênc Saúde Colet [Internet]. 2010 [cited 2015 Oct 12];15(Suppl1):1509-20. Available from: http://www. scielo.br/pdf/csc/v15s1/063.pdf

10. Fortuna CM, Mishima SM, Matumoto S, Pereira MJB, Ogata MN. The research and association between teaching and care in the 
consolidation of the Brazilian National Health System. Rev Esc Enferm USP [Internet]. 2011 [cited 2015 Oct 12];45(spe2):1696700. Available from: http://www.scielo.br/pdf/reeusp/v45nspe2/en_10.pdf

11. Focault M. Microfísica do poder. 28 ed. São Paulo: Paz \& Terra, 2014.

12. Foucault, M. Vigiar e Punir: nascimento da prisão. Ramalhete R (trad). 42ª Ed. Petrópolis, RJ: Vozes; 2013.

13. Araraquara. São Paulo. Secretaria Municipal de Saúde. Prefeitura Municipal de Araraquara, 2012.

14. Bardin L. Análise de Conteúdo. Lisboa: Edições 70; 2011.

15. Foucault, M. História da sexualidade: a vontade de saber. Albuquerque MTC (trad.). Rio de Janeiro: Paz e Terra; 2014.

16. Merhy EE, Feuerwerker, LCM, Cerqueira P, Franco TB. Diálogos Pertinentes: micropolítica do trabalho vivo em ato e o trabalho imaterial. Novas subjetivações e disputas por uma autopoiese anticapitalística no mundo da saúde. Rio de Janeiro: Lugar Comum (UFRJ);(1):155-78. 2014.

17. Brasil. Ministério da Saúde. Secretaria de Atenção à Saúde. Política Nacional de Humanização. Formação e intervenção. Cadernos Humaniza SUS: v. 1 [Internet]. Brasília: Ministério da Saúde; 2010 [cited 2016 Oct 02]. 242p. Available from: http://bvsms.saude. gov.br/bvs/publicacoes/cadernos_humanizaSUS.pdf

18. Osmo A, Schraiber LB. The field of Collective Health: definitions and debates on its constitution. Saúde Soc [Internet]. 2015 [cited 2015 Oct 20];24(Suppl1):205-18. Available from: http://www.scielo.br/pdf/sausoc/v24s1/en_0104-1290-sausoc-24-s1-00205.pdf

19. Oliveira CLC. Apontamentos teórico-conceituais sobre processos avaliativos considerando as múltiplas dimensões da gestão do cuidado em saúde. Interface [Internet]. 2011 [cited 2016 Oct 02];15(37) Available from: http://redalyc.org/articulo. oa?id $=180119116005$

20. Miranda LR, Francisco JU, Artmann E. Trabalho em equipe interdisciplinar de saúde como um espaço de reconhecimento: contribuições da teoria de Axel Honneth. Physis [Internet]. 2012 [cited 2015 Oct 20];22(4):1563-83. Available from: http://www. scielo.br/pdf/physis/v22n4/a16v22n4.pdf

21. Campos GWS. Cogestão e neoartesanato: elementos conceituais para repensar o trabalho em saúde combinando responsabilidade e autonomia. Ciênc Saúde Colet [Internet]. 2010 [cited 2016 Oct 02];15(5):2337-44. Available from: http://www.scielo.br/pdf/csc/ v15n5/v15n5a09.pdf

22. Scherer MDA, Pires DEP, Jean R. A construção da interdisciplinaridade no trabalho da Equipe de Saúde da Família. Ciênc Saúde Colet [Internet]. 2013 [cited 2015 Oct 20];18(11):3203-12. Available from: http://www.scielo.br/pdf/csc/v18n11/11.pdf

23. Barrios STG, Prochnow AG, Ferla AA, Brêtas ACP. Formação acadêmica e atuação profissional no contexto de um Colegiado de Gestão Regional. Rev Bras Enferm [Internet]. 2012 [cited 2015 Oct 20];65(5):815-21. Available from: http://www.scielo.br/pdf/ reben/v65n5/15.pdf

24. Feuerwerker LCM. Micropolítica e saúde: produção do cuidado, gestão e formação. Porto Alegre: Rede UNIDA; $2014.174 p$.

25. Lessa ABSL, Araújo CNV. A enfermagem brasileira: reflexão sobre sua atuação política. REME Rev Min Enferm [Internet]. 2013 [cited 2016 Oct 02];17(2):474-80. Available from: http://www.reme.org.br/artigo/detalhes/664

26. Vicenzi RB, Girardi MW, Lucas CAS. [Leadership in Family Health (PSF): a view through the perspective of power flows]. S\&TS/H\&SC [Internet]. 2010[cited 2016 Oct 02];1(1)82-7. Available in: http://incubadora.periodicos.ufsc.br/index.php/saudeetransformacao/ article/view/412/454

27. Conselho Federal de Enfermagem. Resolução COFEN-238 de 30 de agosto de 2000 [Internet]. Brasília, 2000 [cited 2013 Oct 02]. Available from: http://novo.portalcofen.gov.br/resoluo-cofen-2382000 4278.html.

28. Cunha GT, Campos GWS. Method Paideia democratic management at work. Org Demo [Internet]. 2010 [cited 2016 Oct 02]; 11(1):31-46. Available from: http://www.marilia.unesp.br/Home/Publicacoes/org\&demo\%20v11,\%20n1 2010.pdf.

29. Foucault M. O sujeito e o poder. In: Dreyfus H, Rabinow P. Michel Foucault, uma trajetória filosófica: para além do estruturalismo e da hermenêutica. Rio de Janeiro: Forense Universitária; 2010. 384 p.

30. Foucault M. Ditos e escritos: ética, sexualidade, política, (vol V). S. Paulo: Forense Universitária; 2012.392 pg. 